\section{AB0545 DYNAMICS OF N-TERMINAL FRAGMENT OF BRAIN NATRIURETIC PEPTIDE PROGENITOR LEVEL IN PATIENTS WITH SYSTEMIC LUPUS ERYTHEMATOSUS, WITHOUT HEART FAILURE SIGNS BEFORE AND AFTER IMMUNOSUPPRESSIVE THERAPY}

Tatiana Panafidina ${ }^{1}$, Tatiana Popkova ${ }^{1}$, Maria Cherkasova ${ }^{2}{ }^{1}$ V.A.Nasonova Research Institute of Rheumatology, Systemic rheumatic diseases, Moscow, Russian Federation; ${ }^{2}$ V.A.Nasonova Research Institute of Rheumatology, Laboratory department, Moscow, Russian Federation

Background: Cardiovascular mortality is increased in systemic lupus erythematosus (SLE). Elevated plasma concentration of $\mathrm{N}$-terminal fragment of brain natriuretic peptide progenitor (NT-proBNP) is a laboratory marker of heart failure (HF), associated with cardiovascular morbidity and mortality in the general population.

Objectives: To measure NT-proBNP serum levels in SLE patients without HF signs before initiation of the therapy. To monitor NT-proBNP levels during therapy up to achieving SLE remission.

Methods: The study included 15 patients (87\% females, aged 31[29-33] years (median [interquartile range 25-75\%]) with untreated SLE (ACR 1997 and SLICC 2012 criteria) without HF. These were patients with a new-onset and long-standing disease, who discontinued administered therapy. The control included 39 healthy donors (27[24-44]years, $87 \%$ females). A comprehensive SLE patients' evaluation was made twice: at baseline and at the end of follow up (FUP), median FUP was 7[2-7] years. Serum levels of NT-proBNP $(\mathrm{pg} / \mathrm{ml})$ were measured using electrochemiluminescence method Elecsys proBNP II (Roche Diagnostics, Switzerland). Normal NT-proBNP levels should vary within $\leq 125 \mathrm{pg} / \mathrm{ml}$.

Results: At enrollment medial SLE duration was 1[1-7]years, SLEDAI-2K 10[8-20], SLICC/DI - 0[0-1]scores, SLE patients had elevated (vs controls) values of NT-proBNP: $150,7[77,6-550,2]$ vs $44,6[29,7-66,91] \mathrm{pg} / \mathrm{ml}, p<0,001$, NT-proBNP concentrations $>125 \mathrm{pg} / \mathrm{ml}$ were found in $8(53 \%)$ SLE patients without HF. Glucocorticoids and hydroxychloroquine were initiated in all patients, and additionally cyclophosphamide was administered in $7(47 \%)$ patients, mycophenolate mofetil - in 10(67\%), azathioprine - in $5(33 \%)$, rituximab - in $3(20 \%)$. By the end of FUP patients' median age was 36 [34-39]years $p<0,001$, SLE duration - 8[7,5-11]years, stable remission was achieved in $14(93 \%)$ patients, a relapse of exacerbation was documented in $1(7 \%)$ patient, SLEDAI-2K - 2[0-4] $p<0,01, \quad$ SLICC/DI - 1[0-2]scores $p<0,05$, NT-proBNP levels were comparable to values in the control group: $26,6[19,3-64,9]$ vs $44,6[29,7-66,91] \mathrm{pg} / \mathrm{ml}, p>0,05$, with only one case $(7 \%)$ with NT-proBNP level $>125 \mathrm{pg} / \mathrm{ml}$.

Median NT-proBNP concentration dropped from $150,7[77,6-550,2]$ to 26,6 $[19,3-64,9] \mathrm{pg} / \mathrm{ml}, \quad p<0,001$ when remission was achieved, therefore baseline rate of $53 \%$ of participants with elevated NT-proBNP concentration decreased to $7 \%, p<0,01$. Patients achieving SLE remission on treatment also succeeded to normalize their NT-proBNP levels, and didn't show any signs of cardiovascular (CV) pathology or HF.

In "naïve" to treatment SLE patients NT-proBNP levels showed positive correlation with concentrations of creatinine $(r=0,614, \quad p<0,05)$, urea $(r=0,614, p<0,05)$, and also with interventricular septum myocardial thickness $(r=0,557, p<0,05)$, and showed negative correlation with glomerular filtration rate (GFR) $(r=-0,579, p<0,05)$. There was no association between NT-proBNP levels and clinical \& immunological SLE features, as well as markers of inflammation (CRP, IL-6, TNF- $\alpha$ ), and TRF.
Conclusion: NT-proBNP concentrations in "untreated" SLE patients with high disease activity and without CV pathology and HF were significantly higher than in the control group $(p<0,001)$, and more than $50 \%$ of these patients had elevated NT-proBNP $(>125 \mathrm{pg} / \mathrm{ml})$ baseline concentration. Elevated NT-proBNP concentrations were associated with markers renal function (creatinine, urea, GFR). Adequate immunosuppressive therapy resulted in achievement of SLE remission and normalization of NTproBNP concentrations.

Disclosure of Interests: None declared

DOI: 10.1136/annrheumdis-2019-eular.7205

\section{AB0546 IS IMMUNOLOGICAL PROFILE THE PRIMARY DRIVING FORCE BEHIND CLINICAL PICTURE OF SJÖGREN SYNDROME?}

Katja Perdan-Pirkmajer ${ }^{1,2}$, Alojzija Hocevar ${ }^{1,2}$, Ziga Rotar $^{1}$, Matija Tomsic $^{1,2}$, Natasa Gaspersic ${ }^{1}$, Sonja Praprotnik ${ }^{1,2}$. ${ }^{1}$ University Medical Centre Ljubljana, Rheumatology, Ljubljana, Slovenia; ${ }^{2}$ University of Ljubljana, Faculty of Medicine, Ljubljana, Slovenia

Background: Primary SS (pSS) is a unique autoimmune disorder with a diverse spectrum of clinical and serological manifestations. Multiple clinical and laboratory determinants have been suggested to affect disease progression. Among these, early-onset (up to 35 years) has been proposed to indicate more severe disease ${ }^{1}$

Objectives: To determine possible clinical and laboratory differences between pSS patients diagnosed at 35 years or younger and those diagnosed after the age of 35 .

Methods: We analyzed a single-centre cohort of 228 adult patients with pSS. For 189 consecutive patients diagnosed between the years 2002 and 2008, the data were collected retrospectively from medical charts, while 39 consecutive patients diagnosed from 2016 to 2018 were followed prospectively. Clinical and laboratory data at diagnosis were collected as defined by ESSDAl. The patients were monitored for new organ involvement during the follow-up period. Categorical variables were compared between those diagnosed $\leq 35$ years and after 35 years using the $\chi^{2}$-test or Fisher's exact test. Continuous variables were compared using the Mann-Whitney $\mathrm{U}$ test. A multivariate logistic regression model was used to test the association between early- and over 35 years-onset pSS, anti-SSA positivity, baseline ESSDAI, the duration of follow-up period and the progression of pSS defined as new organ involvement during the follow-up period.

Results: All patients in our cohort fulfilled the 2002 classification criteria 2. There were 24 (87.5\% female, median age 32.5 (IQR 29-34)) earlyonset patients and 204 (92.9\% female, median age 59 (IQR 51-67)) patients diagnosed after the age of 35 . The patients were monitored for new organ involvement during the follow-up period ((6.5 (IQR 3-13) years in the early-onset group and 5 (IQR 2-10) years in the > 35 years group). The early-onset group presented with a significantly higher frequency of salivary gland enlargement $(25.0 \%$ vs $7.8 \%, p=0.017)$, cutaneous involvement $(25.0 \%$ vs $5.9 \%, p=0.006)$ cryoglobulinaemia $(37.5 \%$ vs $12.3 \%, p<0.004)$, RF positivity $(50 \%$ vs $25.5 \%, p<0.028)$, anti-SSA positivity $(87.5 \%$ vs $51.5 \% \quad(\mathrm{p}<0.001)$ and anti-SSb positivity $(50 \%$ vs $22.8 \%(p<0.004)$. The presence of anti-SSA (odds ratio (OR) $3.93,95 \%$ $\mathrm{Cl} 1.69-9.12, p=0.001$ ), and longer period of follow-up (OR 1.16, $95 \% \mathrm{Cl}$ $1.09-1.25, \quad p<0.001$ ), but not early onset of pSS (OR $0.68,95 \% \mathrm{Cl}$

\begin{tabular}{|c|c|c|c|c|c|c|c|c|c|c|c|c|c|}
\hline Case & $\begin{array}{c}\text { Age } \\
\text { (years) }\end{array}$ & & SLE & $\begin{array}{l}\text { volution } \\
\text { ime }\end{array}$ & & SLEDAI & Diarrhea & & $\begin{array}{l}\text { Abdominal } \\
\text { pain }\end{array}$ & & Vomit & Sickness & Fever \\
\hline 1 & 29 & & & years & & 29 & 0 & & 1 & & 1 & 1 & 0 \\
\hline 2 & 24 & & & jears & & 24 & 1 & & 1 & & 1 & 0 & 1 \\
\hline 3 & 25 & & & years & & 25 & 1 & & 1 & & 0 & 0 & 0 \\
\hline 4 & 23 & & & jears & & 23 & 1 & & 1 & & 0 & 0 & 0 \\
\hline 5 & 16 & & & onths & & 16 & 1 & & 1 & & 1 & 1 & 0 \\
\hline 6 & 22 & & & onths & & 23 & 1 & & 1 & & 0 & 1 & 0 \\
\hline ANA & AntiDNAds & C3 & $\mathrm{C} 4$ & $\begin{array}{l}\text { CRP } \\
\mathrm{mg} / \mathrm{dl}\end{array}$ & Leukocytes & $\begin{array}{c}\text { Hemoglobin } \\
(\mathrm{g} / \mathrm{dl})\end{array}$ & $\begin{array}{c}\text { Creatinine } \\
(\mathrm{mg} / \mathrm{dl})\end{array}$ & Proteinuria & $\begin{array}{l}\text { Kidney } \\
\text { Biopsy }\end{array}$ & $\begin{array}{c}\text { CT } \\
\text { Findings }\end{array}$ & Treatment & \multicolumn{2}{|c|}{ Intestinal Biopsy } \\
\hline $\begin{array}{l}\text { Homogeneous } \\
1: 1280\end{array}$ & NA & 60 & 12 & 12.3 & 8.5 & 8.3 & 1.45 & $0.3 \mathrm{gr} / \mathrm{tt}$ & NA & $\begin{array}{c}\text { Target } \\
\text { Shooting }\end{array}$ & $\begin{array}{c}\mathrm{mPDN}+ \\
\mathrm{CYC}\end{array}$ & \multicolumn{2}{|c|}{ NA } \\
\hline $\begin{array}{l}\text { Homogeneous } \\
1: 1280\end{array}$ & NA & 27 & 7.6 & 5.9 & 15.6 & 12 & 1.06 & $0.22 \mathrm{gr} / \mathrm{tt}$ & NA & $\begin{array}{l}\text { Target } \\
\text { Shooting }\end{array}$ & $\begin{array}{l}\mathrm{mPDN}+ \\
\mathrm{CYC}\end{array}$ & \multicolumn{2}{|c|}{ NA } \\
\hline $\begin{array}{l}\text { Fine speckled } \\
1: 320\end{array}$ & NA & 34.5 & 10 & 1.6 & 7.38 & 16 & 0.82 & $1 \mathrm{gr} / \mathrm{tt}$ & NA & $\begin{array}{l}\text { Target } \\
\text { Shooting }\end{array}$ & $\begin{array}{c}\text { mPDN + } \\
\text { MMF }\end{array}$ & \multicolumn{2}{|c|}{ NA } \\
\hline $\begin{array}{l}\text { Homogeneous } \\
1: 1280\end{array}$ & NA & 102.2 & 22 & 0.3 & 8.1 & 12.2 & 0.9 & $>3 \mathrm{gr} / \mathrm{lt}$ & NA & $\begin{array}{l}\text { Target } \\
\text { Shooting }\end{array}$ & $\begin{array}{l}\mathrm{mPDN}+ \\
\mathrm{CYC}\end{array}$ & \multicolumn{2}{|c|}{$\begin{array}{l}\text { Rectal ampulla biopsy: Chronic } \\
\text { non-specific mild colitis }\end{array}$} \\
\hline $\begin{array}{l}\text { Homogeneous } \\
1: 1280\end{array}$ & $140 \mathrm{UI}$ & 29 & 8 & 0 & 2.6 & 11 & 0.55 & $3 \mathrm{gr} / \mathrm{tt}$ & III & $\begin{array}{l}\text { Target } \\
\text { Shooting }\end{array}$ & $\begin{array}{c}\text { mPDN + } \\
\text { CYC + RTX }\end{array}$ & \multicolumn{2}{|c|}{ NA } \\
\hline $\begin{array}{l}\text { Homogeneous } \\
1: 1280\end{array}$ & NA & 34 & 7 & 0.5 & 8.4 & 10.6 & 1.74 & $>3 \mathrm{gr} / \mathrm{tt}$ & III & $\begin{array}{l}\text { Target } \\
\text { Shooting }\end{array}$ & $\begin{array}{l}\mathrm{mPDN}+ \\
\mathrm{CYC}\end{array}$ & \multicolumn{2}{|c|}{ NA } \\
\hline
\end{tabular}


0.24-1.88, $\mathrm{p}=0.452$ ), were independently associated with new organ involvement during the follow-up. There was a tendency for an association of higher ESSDAI at baseline with adverse outcome (OR 1.06, 95\% $\mathrm{Cl}$ 0.99-1.12, $\mathrm{p}=0.075$ ).

Conclusion: Data from our cohort suggest that more aggressive disease course was associated with the presence of anti-SAA regardless of the age of pSS onset.

\section{REFERENCES}

[1] Anquentil C, et al. Rheumatology (Oxford). 2018 doi:10.1093/rheumatology/key392.

[2] Vitali C, et al. Ann Rheum Dis 2002;61:554-8.

Disclosure of Interests: None declared

DOI: 10.1136/annrheumdis-2019-eular.4986

\section{$\mathrm{AB} 0547$ \\ LUPUS ENTERITIS SERIES OF CASES IN DEVELOPING COUNTRY: FROM CLINICAL FINDINGS TO THERAPEUTIC MANAGEMENT}

Gustavo Razo, Diego Felipe Garcia Rodriguez, David Alejandro Herrera Van Oostdam, Carlos Abud-Mendoza, Enrique Cuevas Orta, Alejandra Perez, Luis Gonzalo Hernandez. Hospital Central "Ignacio Morones Prieto", Rheumatology, San Luis Potosi, Mexico

Background: The prevalence of lupus enteritis (LE) is $2 \%$ one of gastrointestinal manifestation of the involvement of the LES. The rapid onset of these symptoms requires determining the life-threatening conditions, but their detection becomes a challenge. We present a series of 6 cases of LE, the most clinical findings and limitations in our environment.

Objectives: Our objective was to describe six cases of lupus enteritis, its diagnostic challenge in our country with limited resources, frequent clinical presentations and its management.

Methods: We retrospectively reviewed the medical records of 6 patients in our hospital with a diagnosis of SLE according to SLICC ACR 2010 criteria between 2017-2018 for suspicion of lupus enteritis. we discard infectious etiology.

\begin{tabular}{|c|c|c|c|c|c|c|c|c|}
\hline Case & $\begin{array}{c}\text { Age } \\
\text { (years) }\end{array}$ & $\begin{array}{c}\text { SLE } \\
\text { evolution } \\
\text { time }\end{array}$ & SLEDAl & Diarrhea & $\begin{array}{c}\text { Abdominal } \\
\text { pain }\end{array}$ & Vomit & Sickness & Fever \\
\hline 1 & 29 & 12 years & 29 & 0 & 1 & 1 & 1 & 0 \\
\hline 2 & 24 & 2 years & 24 & 1 & 1 & 1 & 0 & 1 \\
\hline 3 & 25 & 4 years & 25 & 1 & 1 & 0 & 0 & 0 \\
\hline 4 & 23 & 1 years & 23 & 1 & 1 & 0 & 0 & 0 \\
\hline 5 & 16 & 6 months & 16 & 1 & 1 & 1 & 1 & 0 \\
\hline 6 & 22 & 8 months & 23 & 1 & 1 & 0 & 1 & 0 \\
\hline
\end{tabular}

\begin{tabular}{|c|c|c|c|c|c|c|c|c|c|c|c|c|}
\hline$A N A$ & Antopuads & $\mathrm{c}^{\mathrm{B}}$ & ${ }^{c 4}$ & $\underset{\substack{\text { cop } \\
\text { nyydid }}}{2}$ & $\begin{array}{l}\text { Loukase } \\
\text { es }\end{array}$ & 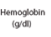 & $\begin{array}{c}\text { cosatinne } \\
\text { (mpgdit) }\end{array}$ & Pretenuria & watany gbpoyy & Crfinenangs & Trexmont & 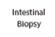 \\
\hline 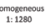 & ma & $\infty$ & 12 & 12.3 & 85 & 8.3 & 145 & ${ }_{038 / \pi}^{03}$ & na & Target Shoosing & mpow + & NA \\
\hline 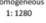 & $\mathrm{ma}$ & 27 & 26 & 5.9 & 15,6 & 12 & 106 & $0.228 / \mathrm{t}$ & $\mathrm{ma}$ & Terget Shooring & MPOH + & m \\
\hline  & na & s.5 & 10 & 1.0 & 738 & 16 & 0.02 & $18 \mathrm{~s} / \mathrm{h}$ & na & Traset Shooting & mPON, sMt & na \\
\hline $1: 1280$ & $\mathrm{NA}$ & 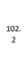 & 22 & 0.3 & 8.1 & 122 & 0.9 & $=3 \mathrm{ef} / \mathrm{ft}$ & $\mathrm{NA}$ & Terget Shooding & $\mathrm{MPON}+\mathrm{CCC}$ & 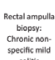 \\
\hline 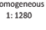 & 1900 & 20 & 8 & 。 & 2.6 & 11 & 0.55 & ${ }^{38 / 1 / 2}$ & "'" & Tereget Shosting & 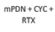 & nA \\
\hline 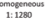 & $\mathrm{na}$ & ${ }_{34}$ & r & as & $\alpha$. & 10.5 & 174 & 3 3effith & "II & 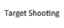 & mpon tocc & NA \\
\hline
\end{tabular}

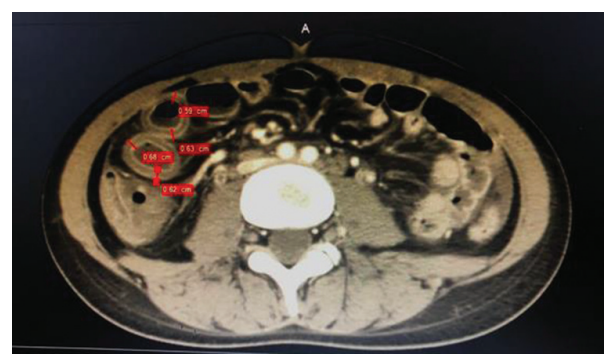

Results: We describe 6 cases, all the patients were woman with a mean age of 23.1 years and an average of 3.6 years until the presentation of enteritis. The clinical symptoms included mainly abdominal pain $(100 \%)$, vomiting $(50 \%)$, diarrhea $(83 \%)$, nausea $(50 \%)$ and fever $(16 \%)$ The laboratory characteristics mainly reflect the high lupus activity: SLEDAI 23 pts. Low levels of complement (83\%), anemia $(50 \%)$. The homogeneous pattern predominated in $83 \%$, antiDNA was quantified only in one patient due to a lack of resources, with high titers. The median level of CRP was $3.3 \mathrm{mg} / \mathrm{dL}$. Only two patients (33\%) presented class III lupus nephritis by biopsy. In CT, the sign of target shot was present in all cases. Only 1 patient could be biopsied with non-specific chronic colitis. All patients received corticosteroids as first-line treatment, with additional immunosuppressants with significant improvement. One patient died due to pulmonary complications.

Conclusion: We should consider lupus enteritis as a possible initial digestive manifestation in patients with SLE. Its diagnosis requires a high index of suspicion, being the CT one of the fundamental pillars for the diagnosis. There is no consensus in the management, however, it was initiated with pulses of methylprednisolone, with limitations to request immunological studies and biological therapy due to economic implications.Finally, we emphasize the need for a prospective evaluation of this rare disease by encouraging the establishment of an international registry.

\section{REFERENCES}

[1] Li Z, Xu D, Wang Z, et al. Gastrointestinal system involvement in systemic lupus erythematosus. Lupus 2017; 26: 1127-1138.

[2] Yang C, Chen S, Gaut JP, Dehner LP. Smooth-muscle myopathy in systemic lupus erythematosus presenting with intestinal pseudo- obstruction. Am J Gastroenterol 2016; 111: 1501-1502

Disclosure of Interests: None declared

DOI: 10.1136/annrheumdis-2019-eular.7297

\section{\begin{tabular}{|l|l}
\hline AB0548 & SELF-REPORTED NEUROPATHIC PAIN IN A COHORT
\end{tabular} OF PRIMARY SJOGREN'S SYNDROME}

Inês Rego de Figueiredo ${ }^{1}$, Julie Norris ${ }^{2}$, Wan Fai $\mathrm{Ng}^{2,3} .{ }^{1}$ Unidade de Doenças Auto-imunes/Medicina 7.2, Hospital de Curry Cabral, Centro Hospitalar Universitário Lisboa Central (CHULC), Lisboa, Portugal; ${ }^{2}$ Newcastle-upon-Tyne Hospitals NHS Foundation Trust, Newcastle-Upon-Tyne, United Kingdom;

${ }^{3}$ Musculoskeletal Research Group, Institute of Cellular Medicine, Newcastle University, Newcastle-Upon-Tyne, United Kingdom

Background: Although pain has been generally accepted being a cardinal symptoms of primary Sjogren's Syndrome (pSS), its cause remains unclear. It can be articular, muscular, neuropathic or related to fibromylagia. Neuropathic pain in pSS has often been associated with peripheral neuropathy, either small-fibre neuropathy or sensory neuropathies, one of the most common neurological complications of pSS.

Objectives: The aim of this work is to assess the prevalence and associated factors of self-reported neuropathic pain in a cohort of pSS.

Methods: Questionnaires for screening for neuropathic pain was giving out during routine clinic appointment. The first part of the questionnaire was adapted from the Neuropathic Pain Questionnaire - Short Form(1). The second part was adapted from the Neuropathic Pain Diagnostic Questionnaire (DN4)(2), but only including the self-reported items (7 items related to symptoms), which is scored with a cut-off value of $\geq 3 / 7$.

Results: Data from 44 patients attending the Sjogren's clinic were analysed, yielding a female preponderance (86\%), with a mean age of 59,6 years old. pSS disease duration on average 9,7 years, antibody positivity of $43 \%$ and $34 \%$ for anti-Ro and anti-La, respectively. 35 had salivary gland biopsy for diagnosis, the majority (48,6\%) having a Focus Score (FS) of $1 ; 28,6 \%$ and $17,1 \%$ with FS of 2 and 3 , respectively. Also worth mentioning 2 patients had lymphoma in the salivary gland biopsy (DLBC and MALT lymphoma). As for disease scores, ESSDAI mean was 